Ніколюк О.В.

доктор економічних наук, профресор

кафедра публічного управління та адміністрування

Email: alenavn11@gmail.com

ORCID ID: 0000-0002-1665-0361

Кирилова В.П.

магістрант

кафедра публічного управління та адміністрування

Одеська національна академія харчових технологій

вул. Канатна 112, м. Одеса, Україна, 65039

E-mail: valyakirillova@ukr.net

ORCID ID: 0000-0003-1142-8849

\title{
УДОСКОНАЛЕННЯ СИСТЕМНОГО ПІДХОДУ ДО НАДАННЯ АДМІНІСТРАТИВНИХ ПОСЛУГ ОДЕСЬКОЇ МІСЬКОЇ РАДИ
}

У статті розглянуто систему надання адміністративних послуг на основі імплементації системного підходу, за допомогою якого ідентифіковано її структуру і функції, надано класифікацію, визначено соціально-економічні зв'язки із зовнішнім середовищем, представлено недоліки у реалізації організаційної, законодавчої, інформаційної функціях представленої системи. Обґрунтовано підходи до інтеграції сучасних інформаційно-комунікаційних технологій із процесами надання адміністративних послуг, передбачаючи вжиття на загальнодержавному рівні дієвих заходів у напрямку розробки державних програм для безкоштовного навчання населення, використання універсальних програмних продуктів для представників органів місцевого самоврядування й інших суб'єктів щодо надання адміністративних послуг Одеської міської ради із метою спрощення їх існуючих процедур, активізація обміну відповідною інформацією між залученими суб'єктами й оптимізації відповідних витрат бюджету. Особливу увагу варто приділяти узагальненню позитивної практики імплементації реформи на рівні Одеської міської ради та вироблення на цих засадах позитивного досвіду щодо реалізації такої реформи.

Ключові слова: управління, адміністративні послуги, публічне управління, системний підхід, система.

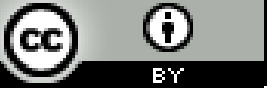

This work is licensed under a Creative Commons Attribution 4.0 International License http://creativecommons.org/licenses/by/4.0/
Постановка проблеми та її зв'язок з важливими науковими та практичними завданнями. Методологія системного підходу для проведення дослідження особливостей надання адміністративних послуг складається із взаємно пов'язаних складових частин й одночасно є визначальною складовою загальної системи адміністрування більш вищого порядку. Вважається, що саме такий підхід генерує системне мислення, яке є дієвим інструментом для керівників різних установ 3 метою підвищення результативності рішень, які ними приймаються. Таким чином системний підхід у його загальному вигляді доцільно представити також як дієвий спосіб мислення у сфері забезпечення організації й управління [1].

Аналіз останніх публікацій по проблемі. Питання перспективності надання адміністративних послуг й проблеми, що пов'язані із процесами їх безпосереднього надання, представлено: В. Авер'яновим, О. Буханевичем, Н. Васильєвою, О. Карпенком, І. Козюрою, І. Коліушком, А. Ліпенцевим та іншими науковцями. Вагомий внесок у вирішення проблем розвитку відповідної системи адміністрати- вних послуг на місцевому рівні здійснили: І. Бригілевич, Т. Маматова, В. Тимощук, Д. Сухінін, Ю. Шаров й інші.

Формулювання цілей дослідження. Метою статті є розробка напрямків удосконалення системного підходу до надання адміністративних послуг Одеської міської ради.

Виклад основних результатів та їх обгрунтування. Як свідчить систематизований досвід щодо наукових досліджень із питань використання системного підходу, саме системі притаманні такі ключові властивості: цілеспрямованість (головна ознака системи), подільність, складність, цілісність, розмаїття складових елементів, чітка структурованість [2]. Із поступовим розвитком системного підходу щодо надання адміністративних послуг паралельно розвивались й технології, які представляли характер взаємодії складових елементів відповідно системи. Насамперед, за використаними етапами розвитку системного підходу до надання адміністративних послуг можна виділити ключові такі технології [3-4]:

1) базова (фундаментальна) - коли споживачі 
відповідних послуг звертаються за їх безпосереднім отриманням до всіх суб'єктів окремо у відповідності до місця розміщення кожного суб'єкта. Основними недоліками такої технології $\epsilon$ : безпосередній контакт кожного заявника із надавачем послуги, у процесі якого можуть виникати корупційні ризики; потреба заявників постійно відвідувати відповідні органи влади, які зазвичай територіально певним чином розпорошені; практична відсутність у кожного такого суб'єкта перспективної можливості формувати зручні й прозорі умови для належного обслуговування заявників, адже це насамперед потребує суттєвих фінансових витрат; практично відсутній контроль за визначеними термінами й порядком надання послуг й інші. Ключовими перевагами $є$ те, що на етапі формування прозорих і якісних умов щодо обслуговування може скорочуватись часовий лаг надання таких послуг.

2) технологія із використанням принципу “єдиного вікна”, що безпосередньо реалізується на основі формування й функціонування різних інтегрованих офісів, у яких доцільно отримати значну частину популярних послуг (насамперед в Україні це центри надання адміністративних послуг). Основними недоліками такої технології є: у деяких випадках суттєво затягуються терміни щодо надання послуг (на етапі надання швидких послуг, коли безпосередньо адміністратор, який приймає документи та суб'єкт для надання відповідної послуги перебувають у різних віддалених будівлях). Основними перевагами є: можливості для формування прозорих і якісних умов для обслуговування громадян, позбавлення їх потреби у відвідуванні органів влади; контроль за встановленими термінами й порядком надання адміністративних послуг; нейтралізація певних корупційних складових на етапі надання відповідних послуг.

3) технологія обслуговування із використанням принципу “віддаленого доступу”, який реалізується у контексті надання перспективної можливості для громадян звертатись за відповідною послугою й отримувати іiї результат використовуючи мережу Iнтернет. У свою чергу, відбувається трансформація існуючих внутрішніх та зовнішніх відносин серед органів публічної влади на засадах використання перспективних можливостей імплементації інформаційно-комунікаційних технологій задля оптимізації адміністративних послуг й реформування внутрішніх процесів.

Досить активно використовується технологія е-урядування, яка передбачає зростання рівня участі всього суспільства щодо державного управління, своєчасного інформування громадян і бізнесу про функціонування державних й місцевих відомств використовуючи засоби Інтернету; також надання адміністративних послуг на ефективних платформах в режимі on-line; всебічне залучення громадян і бізнесу до проведення обговорення й прийняття виважених управлінських рішень; проведення автоматизації діяльності органів влади й міжвідомчої взаємодії.

В сучасній системі щодо надання адміністративних послуг Одеської міської ради оптимальним засобом для впровадження саме технології “віддаленого доступу” є насамперед Єдиний державний портал надання адміністративних послуг, який представляється, як офіційний інформаційний Інтернетресурс, що призначений для реалізації можливості безпосередньо звертатись за послугою й отримувати iii результати також дистанційно у електронній формі, безпосередньо отримувати належну інформацію із таких питань [5].

Основними недоліками (є практично тимчасовими): недостатній рівень обізнаності щодо певної частини громадян у реалізації інформаційних технологій; певним чином недостатнє покриття відведених територій належним доступом до мережі Інтернет; відсутність практичних засобів належного захисту баз даних, що є значно диверсифікованими, ускладнюючи цим самим обмін своєчасною інформацією тощо. До ключових переваг такої технології належать: перспективна можливість замовити й отримати послуги та необхідну інформацію від будь-якого зручного для кожного заявника місця; мінімізація термінів щодо надання послуг; практична нейтралізація корупційної складової; мінімізація витрат на діяльність органів публічної влади й інше. На сьогодні в Україні співіснують різні такі технології щодо надання адміністративних послуг, досить оптимально використовуючи які необхідно удосконалювати процеси для надання таких адміністративних послуг [6].

На етапі децентралізації влади саме органи місцевого самоврядування є одним із найважливіших елементів динамічної системи надання таких адміністративних послуг в Україні, що постійно взаємодіють iз іншими елементами такої системи (відповідними органами державної влади, також фізичними і юридичними особами) задля задоволення інтересів громадян на етапі підготовки, прийняття й видачі документів, або ж інших адміністративних актів, які засвідчують конкретний юридичний статус або ж факт, підтверджуючий безпосередньо набуття, зміну або припинення прав або ж обов'язків фізичної або ж юридичної особи згідно законодавства.

В умовах реалізації реформи із децентралізації в Україні відбувається значне укрупнення територіальних громад і районів та безпосередню передачу повноважень для місцевих адміністрацій органам місцевого самоврядування (зазвичай - на базовий рівень), представляється недалека перспектива для передачі сформованих адміністраціями центрів міським радам. Таким чином представлені заходи наведених міських рад вважаємо, насамперед, нераціональними, адже потребують залучення відповідних додаткових фінансових й кадрових ресурсів, однак все одно не поліпшать рівня якості обслуговування для громадян [7].

Особисті центри міських рад доцільно було б сформувати там, де як результат різних причин відповідно перспектив не змогли належним чином організувати дану роботу на рівні райдержадміністрації та домовитись про надання їм послуг у таких сформованих міських центрах. Варто зауважити, що сформувати центр надання адміністративних послуг (ЦНАП) 
iз належними умовами для обслуговування громадян у таких районах відповідно не вдалось головним чином із причини практичної відсутності належної взаємодії райдержадміністрацій із районними радами, адже на засадах, коли держава певним чином не спромоглась виділити необхідні кошти на облаштування таких центрів, належну підтримку для адміністрацій на їх прохання у інших районах надавали безпосередньо районні ради. Відсутність ефективної взаємодії між Одеською обласною державною адміністрацією також Одеською міською радою й іншими органами виконавчої влади відповідно призвела до поступового згортання блискучого для надання послуг громадянам у сфері надання якісних адміністративних послуг проєкту “Точка Рішень” м. Одеса. Саме тому лише із вересня 2017 року почав безпосередньо працювати новий міський ЦНАП, тільки в іншому приміщенні.

До цього ж послуги надавались у такому приміщенні, який вкрай не пристосоване для надання послуг великій кількості громадян. У свою чергу відомий досвід щодо організації взаємодії серед Вінницької міської ради із іншими органами державної влади й бізнесом різних форм власності, які надають відповідні адміністративні й інші послуги.

Міська рада формує просторі, необхідні офіси із робочими місцями, заповнені необхідною оргтехнікою, динамічною системою управління черги, забезпечення якісного доступу до Інтернету й електронної системи для документообігу, із врахуванням зручних умов для надання якісних послуг громадян й вивченням їх думки щодо якості такого обслуговування. Через такі офіси міська рада залучає до надання значної кількості послуг інших установ й організацій за безпосередньою взаємною домовленістю із такими службами і активній участі для їх співробітників, щоб у одному зручному місті всі громадяни могли отримувати потрібні їм документи й інформацію [8]. Таким чином, саме від рівня безпосереднього налагодження взаємодії між різними органами публічної влади у динамічній системі надання якісних адміністративних послуг залежить відповідний рівень задоволення інтересів й потреб для споживачів таких послуг, які і є системоутворюючим елементом у такій системі. Врегульовуючи питання такої належної взаємодії керівникам для органів публічної влади доцільно відкидати різні власні й політичні амбіції, адже вони заважають безпосередньо якісному обслуговуванню всіх людей.

Як свідчить проведений нами аналіз на сучасному етапі реформування системного підходу до надання адміністративних послуг Одеської міської ради не застосовуються такі важливі механізми, як “регулярний моніторинг та оцінка реалізації реформ", та "інформаційно-комунікаційний супровід реалізації реформ”, що призводить до відсутності комплексного підходу при здійсненні реформування.

Моніторинг та оцінка реалізації реформування системного підходу до надання адміністративних послуг Одеської міської ради є окремими етапами процесу стратегічного планування удосконалення системного підходу до надання адміністративних послуг Одеської міської ради, які передбачають збір та аналіз інформації, необхідної для забезпечення досягнення очікуваних результатів і вдосконалення процесу іiі реалізації (рис.1).

Ще одним важливим механізмом забезпечення ефективної реалізації реформи системного підходу до надання адміністративних послуг Одеської міської ради є iї інформаційно-комунікаційний супровід. В рамках нашого дослідження під “інформаційнокомунікаційним супроводом реформи державного управління" пропонуємо розуміти комплекс заходів, спрямований на формування єдиного інформаційного простору та підвищення ефективності взаємодії органів державної влади та суспільства шляхом покращення поінформованості громадськості про основні завдання та заходи реформи системного підходу до надання адміністративних послуг Одеської міської ради.

Задля сприяння забезпечення відкритого доступу представників громадськості до імплементації завдань й заходів реформи доцільно використання комплексного підходу до забезпечення ії інформаційно-комунікаційного супроводу. Комплексна реалізація заходів з інформаційно-комунікаційного супроводження реформи дозволить:

- залучити громадськість до участі в реалізації реформи орієнтованої на підвищення результативності реалізованих заходів та зростання довіри насамперед до органів влади;

- налагодження зв'язку між Урядом, представниками органів державної влади, місцевого самоврядування, суспільством, бізнес середовищем, міжнародними організаціями на етапі реалізації реформ;

- інформаційна підтримка державних службовців й посадових осіб актуальною інформацією щодо динаміки й масштабів реалізації перспективних змін у системному підході до надання адміністративних послуг Одеської міської ради;

- забезпечувати комунікацій на інформаційні потреби певних цільових груп;

- сформувати ефективний механізм щодо інформаційного супроводу для реалізації різних урядових ініціатив.

3 метою забезпечення зворотного зв'язку суспільства і владних інститутів з питань реалізації реформи системного підходу до надання адміністративних послуг Одеської міської ради доцільно проведення моніторингу в системі публічного управління. Особливу увагу слід приділяти узагальненню кодексів кращої практики проведення реформи на регіональному та місцевому рівні та вироблення на цій основі позитивного досвіду реалізації реформи.

Показниками результативності системи заходів зазначеної кампанії можуть служити:

- частка громадян, які мають уявлення про основні напрямки реалізації реформи системного підходу до надання адміністративних послуг Одеської міської ради, з них - частка громадян, що виражають підтримку основних її основних завдань та заходів;

- частка заходів реформи, які отримали 


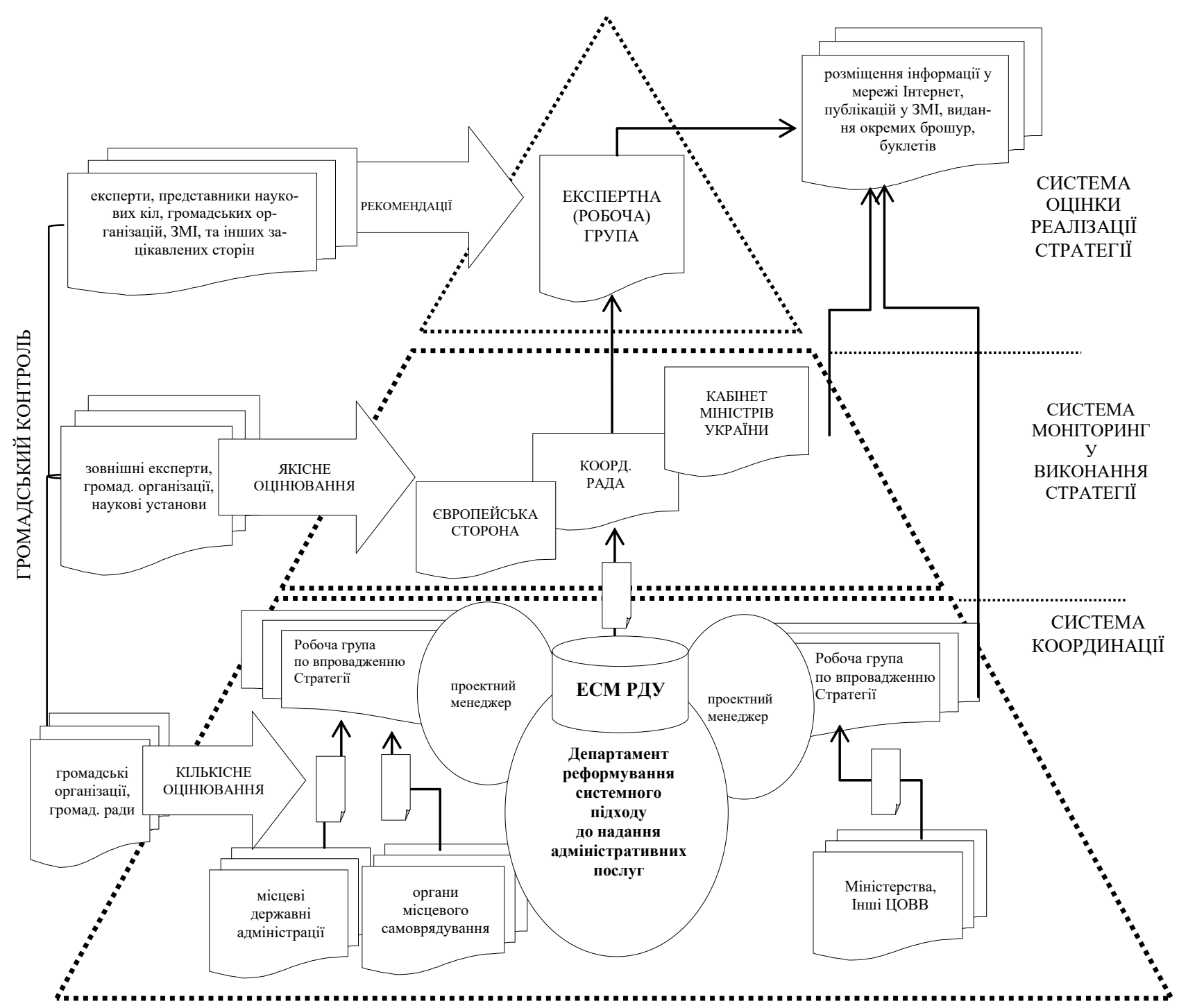

Рис. 1. Моніторинг та оцінка реалізації реформування системного підходу до надання адміністративних послуг Одеської міської ради*

* розроблено авторами

висвітлення в 3МI;

- частка центральних органів виконавчої влади, місцевих державних адміністрації, органів місцевого самоврядування, що регулярно здійснюють інформування громадськості про хід та результати виконання заходів реформи системного підходу до надання адміністративних послуг Одеської міської ради;

- частка 3МІ, які інформують про реалізацію реформи системного підходу до надання адміністративних послуг Одеської міської ради та ін.

Висновки та перспективи подальших досліджень. Розгляд системи надання адміністративних послуг в Україні через призму системного підходу дозволив проаналізувати ії на відповідність загальним властивостям систем, надати їі належну класифікаційну характеристику, згідно якої визначено, що ця система $\epsilon$ відкритою, складною, керованою і добре організованою. Обгрунтовано підходи до інтеграції сучасних інформаційно-комунікаційних технологій із процесами надання адміністративних послуг. Доведено, що від встановленого рівня налагодження процесу взаємодії між представниками публічної влади в динамічній системі надання адміністративних послуг безпосередньо залежить рівень щодо задоволення соціально-економічних інтересів й потреб споживачів таких послуг, які і є безпосередньо системоутворюючим структурним елементом у такій системі. Для забезпечення зворотного зв'язку представників суспільства й владних інститутів щодо реалізації реформи актуальним $є$ проведення моніторингу, що включає проведену оцінку громадянами, відповідними громадськими організаціями, різними представниками бізнес-спільноти змін, які відбуваються в системі надання адміністративних послуг. Використання актуальних інформаційних технологій на етапах надання адміністративних муніципальних послуг (використання технологій е-урядування) $€$ актуальним 
напрямком у всьому світі, адже підвищує доступність наданих послуг для всього населення, надаючи перспективні можливості замовити й отримати послуги на належну інформацію із будь-якого зручного для представленого заявника місця використовуючи Інтернет. Використання таких технологій дозволяє суттєво скоротити терміни для надання послуг; мінімізувати, а в деяких випадках практично нейтралізувати корупційні ризики; мінімізувати витрати на функціонування відповідних органів місцевого самоврядування й інше. Моніторинг і оцінка процесу реалізації реформування системного підходу до надання адміністративних послуг Одеської міської ради є окремими етапами у динамічному процесі стратегічного планування модернізації системного підходу, які передбачають збір й аналіз інформації, необхідної для забез- печення досягнення очікуваних результатів та формування процесу іiі реалізації. В роботі сформовано рекомендації для органів державної влади 3 метою розробки інформаційно-комунікаційного супроводу щодо реалізації реформи системного підходу до надання адміністративних послуг Одеської міської ради. Важливою умовою ефективності реалізації реформи системного підходу до надання адміністративних послуг Одеської міської ради є наявність внутрішньої (співробітників органів публічної влади й органів місцевого самоврядування) та зовнішньої (населення, бізнес-середовища, різних громадських організацій, міжнародної спільноти тощо) інтересу та підтримки прийнятих державних рішень, яка можлива лише на умовах реалізації органами влади різних комунікативних зв'язків із громадськістю.

\section{Література}

1. Клименко І. В. Електронні послуги: навч. посіб. / за заг. ред. Н.В. Грицяк. К.: НАДУ. 2014. 100 с.

2. Бригілевич I.I., Ванько С.І., Загайний В.А. Центри надання адміністративних послуг: створення та організація діяльності: практ. посіб. / за заг. ред. В. П. Тимощука. К.: СПД Москаленко О. М., 2010. 440 с.

3. Матвійчук, Р.М., Кандзюба С.П. Електронні послуги. К.: ФОП Москаленко О. М. 2017. 60 с.

4. Бабаєв В.М. Новікова М.М., Гайдученко С.О. Текст лекцій з дисципліни «Електронне урядування» / Харк. нац. ун-т міськ. госп-ва ім. О. М. Бекетова. Харків: ХНУМГ. 2014. 127 с.

5. Олійник Т. Реінжиніринг адміністративних процесів в органах публічного управління в умовах упровадження електронної взаємодії.

URL: http://dridu.dp.ua/konf/konf_dridu/itis\%20seminar\%202017/pdf/Oliinyk_2.pdf (дата звернення: 1.11.2021)

6. Концепція розвитку системи надання адміністративних послуг органами виконавчої влади: розпорядження Кабінету Міністрів України від 15 лютого 2006 p. № 90-p. URL: https://www.kmu.gov.ua/npas/29277890 (дата звернення: 2.11.2021)

7. Про схвалення Концепції розвитку електронного урядування в Україні: розпорядження Кабінету Міністрів України від 20 вересня 2017 р. № 649-p URL: https://www.kmu.gov.ua/npas/250287124 (дата звернення: 1.11.2021)

8. Про адміністративні послуги: Закон України за станом на 22 верес. 2021 p. URL: https://zakon.rada.gov.ua/laws/show/5203-17 (дата звернення: 1.11.2021)

9. Ніколюк О.В. Напрями удосконалення процесів надання адміністративних послуг в умовах децентралізації влади в Одеській області // Розбудова публічного управління та адміністрування: вимоги часу: колективна монографія / ред. кол.: I.I. Савенко, О.В. Ніколюк, Н.М. Корсікова. Одеська національна академія харчових технологій. Одеса: Друк Південь, Сімекс-прінт, 2021. С. 7-28.

10. Briushkova N.O., Nikoliuk O.V., Dobrianska N.A. Institutionalization of the relationship between government and civil society in the context of management decisions // Економіка: реалії часу. Науковий журнал. 2021. № 1 (53). C. 20-26. URL: https://economics.opu.ua/files/archive/2021/No1/20.pdf. DOI: 10.15276/ETR.01.2021.2. DOI: 10.5281/zenodo.4885297. (дата звернення: 2.11.2021) 


\author{
Nikoliuk 0. \\ Doctor of Economics, Professor \\ Department of Public Administration \\ Email: alenavn11@gmail.com \\ ORCID ID: 0000-0002-1665-0361 \\ Kirilova V. \\ Undergraduate \\ Department of Public Administration \\ Odessa National Academy of Food Technologies \\ Kanatna str., 112 Odesa, Ukraine, 65039 \\ E-mail: valyakirillova@ukr.net \\ ORCID ID: 0000-0003-1142-8849
}

\title{
IMPROVEMENT OF THE SYSTEMATIC APPROACH TO PROVISION OF ADMINISTRATIVE SERVICES OF THE ODESSA CITY COUNCIL
}

The article considers the system of administrative services based on the implementation of a systematic approach, which identifies its structure and functions, provides classification, identifies socioeconomic relations with the environment, presents shortcomings in the implementation of organizational, legislative, informational functions of the system. On the basis of domestic decentralization of power, local governments are one of the key elements of the modern system of administrative services of the Odessa City Council, which interact with other elements of such system (government officials, relevant individuals and legal entities) to meet the socio-economic interests of citizens. preparation, acceptance and issuance of documents, as well as other administrative acts certifying their legal status or the fact that confirms the acquisition, change or termination of the relevant rights or obligations of a natural or legal person in accordance with the law. Approaches to the integration of modern information and communication technologies with the processes of providing administrative services have been substantiated, providing for taking effective measures at the national level to develop state programs for free education, use of universal software products for local governments and other entities to provide administrative services of Odessa City Council in order to simplify their existing procedures, intensify the exchange of relevant information between the entities involved and optimize the relevant budget expenditures. It has been proved that the level of satisfaction of socio-economic interests and needs of consumers of such services, which are directly a system-forming structural element in such a system, specifically depends on the established level of developing the process of interaction between public authorities in a dynamic system of administrative services. In order to provide feedback from representatives of society and government institutions on the implementation of the reform, it is important to conduct monitoring, which includes the assessment of changes in the system of administrative services by citizens, relevant NGOs (non-governmental organizations), various representatives of the business community. Particular attention should be paid to generalizing the positive practice of implementing the reform at the level of the Odessa City Council and developing on this basis a positive experience in implementing such a reform. The main condition for ensuring the effectiveness of such administrative reform is the presence of internal (government officials at various levels) and external (business environment, population, NGOs, the international community, etc.) interest and support for decisions, which are possible only with the support of the authorities of various communicative relations with the public.

Key words: management, administrative services, public administration, system approach, system.

\section{References}

1. Klymenko, I. V. (2014). Elektronni posluhy. (N. V. Hrytsiak, Ed.). NADU.

2. Bryhilevych, I. I., Vanko, S. I., \& Zahainyi, V. A. (2010). Tsentry nadannia administratyvnykh posluh: stvorennia ta orhanizatsiia diialnosti. (V. P. Tymoshchuka, Ed.). SPD Moskalenko O. M.

3. Matviichuk, R. M., \& Kandziuba, S. P. (2017). Elektronni posluhy. FOP Moskalenko O. M.

4. Babaiev, V. M., Novikova, M. M., \& Haiduchenko, S. O. (2014). Tekst lektsii z dystsypliny «Elektronne uriaduvannia». Khark. nats. un-t misk. hosp-va im. O. M. Beketova.

5. Oliinyk, T. Reinzhynirynh administratyvnykh protsesiv $v$ orhanakh publichnoho upravlinnia $v$ umovakh uprovadzhennia elektronnoi vzaiemodii. Retrieved November 1, 2021, from http://dridu.dp.ua/konf/konf_dridu/itis\%20seminar\%202017/pdf/Oliinyk_2.pdf

6. Kontseptsiia rozvytku systemy nadannia administratyvnykh posluh orhanamy vykonavchoi vlady: rozporiadzhennia Kabinetu Ministriv Ukrainy vid 15 liutoho 2006 r. № 90-r. Retrieved November 2, 2021, from https://www.kmu.gov.ua/npas/29277890 
7. Pro skhvalennia Kontseptsii rozvytku elektronnoho uriaduvannia v Ukraini: rozporiadzhennia Kabinetu Ministriv Ukrainy vid 20 veresnia $2017 \quad r$. № 649-r. Retrieved November 1, 2021, from https://www.kmu.gov.ua/npas/250287124

8. Pro administratyvni posluhy: Zakon Ukrainy za stanom na 22 veres. 2021 r. Retrieved November 1, 2021, from https://zakon.rada.gov.ua/laws/show/5203-17

9. Nikoliuk, O. V. (2021). Napriamy udoskonalennia protsesiv nadannia administratyvnykh posluh $\mathrm{v}$ umovakh detsentralizatsii vlady v Odeskii oblasti. In I. I. Savenko, O. V. Nikoliuk, \& N. M. Korsikova (Eds.), Rozbudova publichnoho upravlinnia ta administruvannia: vymohy chasu (pp. 7-28). essay, Druk Pivden, Simeks-print.

10. Briushkova, N. O., Nikoliuk, O. V., \& Dobrianska, N. A. (2021). Institutionalization of the relationship between government and civil society in the context of management decisions. Ekonomika: Realiichasu, (1 (53), $20-26$. Retrieved November 2, 2021, from https://economics.opu.ua/files/archive/2021/No1/20.pdf. doi: 10.15276/ETR.01.2021.2. doi: 10.5281/zenodo.4885297.

Received 20 November 2021

Approved 3 December 2021

Available in Internet 30.12.2021

Цитування згідно ДСТУ 8302:2015

Ніколюк О.В., Кирилова В.П. Удосконалення системного підходу до надання адміністративних послуг Одеської міської ради // Економіка харчової промисловості. 2021. Т.13, вип. 4. C.81-87. doi 10.15673/fie.v13i4.2219

Cite as APA style citation

Nikoliuk, O., \& Kirilova, V. (2021). Improvement of the systematic approach to provision of administrative services of the Odessa City Council. Food Industry Economics, 13(4), 81-87. doi 10.15673/fie.v13i4.2219 